\title{
COMPARATIVE STUDY ON THE BACTERIAL CAUSES OF OVINE KERATOCONJUNCTIVITIS IN NATIVE BREED SHEEP AND GOATS
}

\author{
M.SH. RHAYMAH*; B.Y. RASHEED ${ }^{* *}$ and KH.J. HUSSAIN* \\ * Department of Internal and Preventive Medicine, University of Mosul, Mosul, Iraq. \\ *** Department of Microbiology, College of Veterinary Medicine, University of Mosul, Mosul, Iraq.
}

\section{ABSTRACT}

\section{Received at: 18/3/2013}

Accepted: 3/4/2013
Ocular swabs $(n=136)$ were examined bacteriologically, for isolation and identification of the bacterial causes of keratoconjunctivitis in native sheep and goats during the period from September 2010 to November 2011, in Mosul, Iraq. Results revealed isolation of bacteria from $84.4 \%$ and $61.1 \%$ examined swabs in sheep and goats respectively. The bacterial most prevalent species isolates from sheep included Corynebacterium ovis, followed by Staphylococcus aureus, Bacillus spp., Staph .epidermidis, while, Bacillus spp. were most prevalent, followed by Cor. ovis, Staph. aureus in goats. The results revealed that the most bacterial isolates were sensitive to Norfoxacin and Chloramphenicol.

Key words: Bacterial isolation, Eyes, Keratoconjunctivitis, Sheep, Goats.

\section{INTRODUCTION}

Infectious Ovine keratoconjunctivitis (IOK) has the common name pink eye. This disease affected sheep of all ages, and more prominent in ewes than lambs (NADS, 2004). Keratoconjunctivitis is inflammation of the covering mucosa of the eye, including orbit and the inner surface of the eyelids. When the inflammation extend to layers below the conjunctiva the diseases called keratoconjunctivitis (Radostits et al., 2007). It is recognized as a common condition affecting the eyes of domestic sheep and goats (Martin, 1991). Suppurative infection lead to sever visual loss in developing countries (Upadhyay et al., 1991 and Mayer et al., 1997). The principle cause of keratoconjunctivitis in domestic sheep and goats was Mycoplasma conjunctivae (Baker et al., 2001 and Michael et al., 1972), however NADS (2004) add Chlamydia psittaci, as a common pathogen beside other secondary involved bacteria. By using bacterial culture and PCR (Polymerase Chain Reactions) identification Mycoplasma spp. and Branhamella spp. was the main causes of the disease of bighorn sheep and Silver bell mountains in Arizona (Jansen et al., 2006). Other microorganism such as, Corynebacterium pyogenes, Staphylococcus aureus have been suspected as etiological agents (Egwn et al., 1989 and Martin, 1983). Close contact of sheep and goats when trough feeding enables rapid spread of infection and probably accounts for the high incidence of the disease during winter months (Schoenian, 2008). Outbreaks in weaned lambs may be associated with overcrowding, dust, long grass and flies which have been contaminated by infected tear. Handling of the face and head of lambs when drenching may also provide a means of spread, NADS (2004). Treatment by injection with long acting oxytetracyclin may be practical method (Cleon and Swifts, 1988). Protection from sunlight should be provided, and the complete disease eradication is difficult because the organisms that cause the disease are wide-spread and may persist in carrier animals (GiaCometh et al., 2002). So this article trying to clarify the bacterial responsible for keratoconjunctivitis and its significance in native sheep and goats in Mosul, Iraq.

\section{MATERIALS and METHODS}

One hundred and thirty six ocular swabs (64 sheep, 72 goats) were collected from both eyes of different ages and both sexes native sheep and goats during the period September 2010 to November 2011. Diseased animal show signs of keratoconjunctivitis (blepharospasm and weeping from affected eye, watery tear in early stage followed by the appearance of mucopurulent).

Samples were taken from conjunctivae on the lower eyelid with sterile cotton swabs. Each swab was put in to $2 \mathrm{ml}$ of sterile nutrient broth to prevent desiccation. Specimens were brought to the laboratory within 2 hours of collection (Quiun et al., 1999 and Baas et al., 1977). Swabs were inoculated on 5\% blood agar base, MacConkey agar, Mannitol salt agar. All media were incubated aerobically at 37 $\mathrm{C}^{\mathrm{O}}$ for $24 \mathrm{~h}$ (Quiun et al., 2002). Bacterial colonies 
were studied, the isolates were identified by biochemical test (Barown, 2005). Antibacterial sensitivity tests were carried out on these isolates and included, Tetracycline (TE) $30 \mu \mathrm{g}$, Norfloxacin

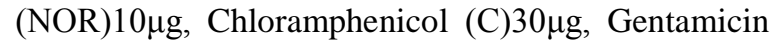
(GN) $10 \mu \mathrm{g}$, Erythromycin (E) $15 \mu \mathrm{g}$ (Koneman et al., 1992 and Seely, 1981).

\section{RESULTS}

The results of present study revealed that the bacterial isolates from infected eyes of goats were $61.1 \%$, including isolation from right eyes $55.6 \%$ and $66.7 \%$ from left one, However in sheep the percentage of bacterial isolates were $84.4 \%$, including $81.3 \%$ from the right eyes and $87.5 \%$ from the left eyes (Table 1).
The most common bacterial isolates in goats were Bacillus spp. $63.6 \%$, Corynebacterium ovis $11.4 \%$, Staphylococcus aureus 6.8\%, Escherichia coli, Staph. epidermidis and Staph. Saprophyticus, $4.5 \%$ for each one, Cor . pilosum and Mould 2.3\% for each one (Table 2). While in sheep it have been detected that Corynebacterium ovis 31.5\%, Staphylococcus aureus 25.9\%, Bacillus spp. 14.8, Staph. epidermidis, $11.1 \%$, Pseudomonas aeruginosa and yeast $5.6 \%$ for each one, Staph. Saprophyticus (3.7\%), and Micrococcus spp. $(1.9 \%)$ (Table3). One sample revealed more than one colony uncommon isolate and ignore. Antibiotic sensitivity test revealed that the most bacterial isolates were sensitive to Norfloxacin and Chloramphenicol except E. coli and Pseudomonas aeruginosa (Table 4).

Table 1: Percentage of infected eye swabs collected from sheep and goats.

\begin{tabular}{ccc}
\hline Direction of the eye & \multicolumn{2}{c}{ Animal species } \\
\cline { 2 - 3 } & Sheep & Goats \\
\hline Right eye & $26 / 32$ & $20 / 36$ \\
No. of positive/No. of sample & $(81.3)$ & $(55.6)$ \\
$(\%)$ & & $24 / 36$ \\
\hline Left eye & $28 / 32$ & $(66.7)$ \\
No. of positive /No. of sample & $(87.5)$ & \\
(\%) & & $44 / 72$ \\
Total & $54 / 64$ & $(61.1)$ \\
\hline
\end{tabular}

Table 2: Bacterial species isolated from Goats affected with Keratoconjunctivitis.

\begin{tabular}{lccc}
\hline \multicolumn{1}{c}{ Bacterial species } & \multicolumn{2}{c}{ Direction of the eye } & Total \\
\cline { 2 - 4 } & Right & Left & (\%) \\
\hline Bacillus spp & 14 & 14 & $28(63.6)$ \\
\hline Corynebacterium ovis & 2 & 3 & $5(11.4)$ \\
\hline Staphylococcus aureus & 1 & 2 & $3(6.8)$ \\
\hline Staph .saprophyticus & - & 2 & $2(4.5)$ \\
\hline Staph. Epidermidis & - & 2 & $2(4.5)$ \\
\hline Escherichia coli & 1 & 1 & $2(4.5)$ \\
\hline Cor.pilosum & 1 & - & $1(2.3)$ \\
\hline Mould & 1 & - & $1(2.3)$ \\
\hline Total & 20 & 24 & 44 \\
$(\%)$ & $(45.5)$ & $(54.5)$ & $(100)$ \\
\hline
\end{tabular}

Table3: Bacterial species isolated from sheep affected with keratoconjunctivitis.

\begin{tabular}{lccc}
\hline \multicolumn{1}{c}{ Bacterial species } & \multicolumn{2}{c}{ Direction of the eye } & Total \\
\cline { 2 - 4 } & Right & Left & (\%) \\
\hline Corynebacterium ovis & 8 & 9 & $17(31.5)$ \\
\hline Staphylococcus aureus & 7 & 7 & $14(25.9)$ \\
\hline Bacillus spp & 4 & 4 & $8(14.8)$ \\
\hline Staph. Epidermidis & 3 & 3 & $6(11.1)$ \\
\hline Pseudomonas aeruginosa & 1 & 2 & $3(5.6)$ \\
\hline Yeast & 1 & 2 & $3(5.6)$ \\
\hline Staph. Saprophyticus & 1 & 1 & $2(3.7)$ \\
\hline Micrococcus spp & 1 & - & $1(1.9)$ \\
\hline Total & 26 & 28 & 54 \\
$(\%)$ & $(48.1)$ & $(51.9)$ & $(100)$ \\
\hline
\end{tabular}


Table 4: Antibiotics sensitivity test for bacterial species isolated from keratoconjunctivitis in sheep and goats.

\begin{tabular}{lccccc}
\hline \multicolumn{1}{c}{ Bacterial species } & TE & NOR & C & GN & E \\
\hline Corynebacterium ovis & $\mathrm{R}$ & $\mathrm{S}$ & $\mathrm{S}$ & $\mathrm{S}$ & $\mathrm{S}$ \\
\hline Cor. pilosum & $\mathrm{R}$ & $\mathrm{S}$ & $\mathrm{S}$ & $\mathrm{S}$ & $\mathrm{S}$ \\
\hline Staphylococcus aureus & $\mathrm{S}$ & $\mathrm{S}$ & $\mathrm{S}$ & $\mathrm{R}$ & $\mathrm{S}$ \\
\hline Staph. epidermidis & $\mathrm{S}$ & $\mathrm{S}$ & $\mathrm{S}$ & $\mathrm{R}$ & $\mathrm{S}$ \\
\hline Staph. saprophyticus & $\mathrm{S}$ & $\mathrm{S}$ & $\mathrm{S}$ & $\mathrm{R}$ & $\mathrm{R}$ \\
\hline Bacillus spp & $\mathrm{ND}$ & $\mathrm{ND}$ & $\mathrm{ND}$ & $\mathrm{ND}$ & $\mathrm{ND}$ \\
\hline Escherichia coli & $\mathrm{S}$ & $\mathrm{R}$ & $\mathrm{S}$ & $\mathrm{R}$ & $\mathrm{R}$ \\
\hline Pseudomonas aeruginosa & $\mathrm{S}$ & $\mathrm{S}$ & $\mathrm{R}$ & $\mathrm{R}$ & $\mathrm{R}$ \\
\hline Micrococcus spp & $\mathrm{S}$ & $\mathrm{S}$ & $\mathrm{S}$ & $\mathrm{S}$ & $\mathrm{S}$ \\
\hline S: sensitive, R: & & & & &
\end{tabular}

S: sensitive, R: resistance, ND: not done

TE: Tetracycline, NOR: Norfloxacin, C: Chloramphenicol, GN: Gentamicin, E: Erythromycin

\section{DISCUSSION}

Infectious keratoconjunctivitis is considered a worldwide disease of sheep and goats (GiaCometh et al., 2002). Results of the present study revealed different bacterial isolates identified from affected both eyes in goats and sheep, in percentage $(61.1 \%)$ and $(84.4 \%)$ respectively, Aitken (2007) mentioned that the keratoconjunctivitis may affected one or both eyes and the disease animal show hyperemia of the vessels, lacrimation, corneal opacity and photophobia. The case may progress to mucopurulent conjunctivitis and corneal ulceration resulting in corneal opacity and transient blindness. Bacterial isolates from affected animal in both species revealed different species of bacterial isolation such as Corynebacterium spp, Staphylococcus aurous, Bacillus spp., Escherichia coli, Pseudomonas aeruginosa, and Micrococcus spp. These isolates were also detected by GiaCometh et al. (2002); Akerstedt and Hofshagen, (2004) and Dagnall, (1994). Moreover Fungi was isolated from conjunctivitis of goats and sheep the Similar results were reported by Baas et al. (1977) and Langford, (1971). Other samples were negative for bacteriological isolation because the disease occurred due to other microorganisms such as viral infection, Chlamydia and Mycoplasma infection Michael et al. (1972); Egwn et al. (1989) and Andrews et al. (1987). Results of antibiotics sensitivity test show high sensitivity of bacterial isolates to the antibiotics used except E. coli and Pseudomonas aeruginosa. These results agreement with Al- Rashidy, (1998) who found that the bacterial isolates were sensitive for Norfloxacin and Chloramphenicol. However E. coli and Pseudomonas aeruginosa were most bacteria which was resistant to antibiotics due to many factors related to the causative agents itself or natural as well as acquired resistance of the microorganisms Koneman et al. (1992).

\section{ACKNOWLEDGMENT}

This work was supported by College of Veterinary Medicine, University of Mosul.

\section{REFERENCES}

Aitken, I.D. (2007): Diseases of sheep. $4^{\text {th }}$ ed. Oxford: Blackwell Publishing; p.342-343.

Akerstedt, J. and Hofshagen, M. (2004): Bacteriological Investigation of infectious keratoconjunctivitis in Norwegian sheep. Acta. Vet Scand. 45: 19-26.

Al-Rashidy, S.D. (1998): Common bacterial eye affections in cows and sheep in Mosul Master's thesis : College of Veterinary Medicine, Mosul University, Iraq.

Andrews, A.H.; Goddard, P.C.; Wilsmore, A.J. and Dagnall, G.J.R. (1987): A Chlamydial keratoconjunctivitis in a British sheep flock. Vet Rec. 120: 238-9.

Baas, E.J.; Trotter, S.L.; Franklin, R.M. and Barile, M.F. (1977): Epidemic caprine keratoconjunctivitis: Recovery of Mycoplasma conjunctivae and its possible role in pathogenesis. Infection and Immunity J.;18 (3): 806-815.

Baker, S.E.; Bashiruddin, J.B.; Ayling, R.D. and Nicholas, R.A. (2001): Molecular detection of Mycoplasma conjunctivae in English sheep affected by infectious keratoconjunctivitis. Vet. Rec. 148: 240-241.

Barown, A.E. (2005): Microbiological applications. $9^{\text {th }}$ ed. New York: McGraw-Hill Companies p.8299, 100-125. 
Cleon, V.K. Jensen and Swifts. (1988): diseases of sheep. $3^{\text {rd }}$ ed. Philadelphia: Lea and Febiger.p. 183-184.

Dagnall, G.J.R. (1994): An investigation of colonization of the conjunctival sac of sheep by bacteria and Mycoplasma. Epidemiol Infect.: 112: 561-567.

Egwu, G.O.; Faull, W.B.; Bradbury, J.M. and Ciarkson, M.J. (1989): Ovine infectious keratoconjunctivitis: a microbiological study of clinically unaffected and affected sheep eyes with special reference to Mycoplasma conjunctivae. Vet. Rec. 125: 253-256.

Giacometti, M.; Janovsky, M.; Belloy, L. and Frey, J. (2002): Infectious keratoconjunctivitis of ibex, chamois and other caprinae .Rev Sci Tech of Int. Epiz. ; 21(2): 335-345.

Jansen, B.D.; Heffelfinger, J.R.; Noon, T.H.; Krausman, P.R. and Devos, J.C. (2006): Infectious keratoconjunctivitis in bighorn sheep, silver Bell mountains in Arizona. J. Wild Life Diseases; 42 (2): 407-411.

Koneman, E.W.; Schreckenberger, P.C.; Allen, S.D.; Winn, W.C. and Janda, W.M. (1992): Diagnostic microbiology. $4^{\text {th }}$ ed. Philadelphia: J.B. Lippincott Company; p. 609-630: 171-220.

Langford, E.V. (1971): Mycoplasma and associated bacteria isolated from ovine pink-eye. Can J. Med.; 35: 18-21.

Martin, W.B. (1983): Diseases of sheep. London: Blackwell Scientific Publications; p.214-215.

Martin, W.B. (1991): Diseases of sheep. London: Blackwell Scientific Publications; Pp.: 280-283.

Mayer, D.; Degiorgis, M.P.; Meier, W.; Nicolet, J. and Giacometti (1997): Lesions associated with infectious keratoconjunctivitis in alpine ibex. J Wild Dis. 33:413-419.

Michael, F.B.; Richard, A.D. and Joseph, G.T. (1972): Isolation and characterization of Mycoplasma conjunctivae sp.n from sheep and goats with keratoconjunctivitis. J. Infect. Immun. 5(1):70-76.

NADIS (2004): National Animal Disease Information Service. Infectious keratoconjunctivitis (OIKC) Pink eye; 2004 html.

Quiun, P.J.; Markey, B.K.; Carter, M.E.; Donnelly, W.J. and Leonard, F.C. (2002): Veterinary Microbiology and Microbial diseases . USA: Blackwell Publishing Company; p.23-26.

Quiun, P.J.; Carter, M.E.; Markey, B. and Caster, G.R. (1999): Clinical Veterinary Microbiology .USA: Mosoby An Imprint of Elsevier Limited; p.284-285.

Radostits, O.M.; Gay, C.C; Hinchcliff, K.W. and Constable, P.D. (2004): Veterinary Medicine A textbook of the diseases of cattle, horses, sheep, pigs and goats. $10^{\text {th }}$ ed. New york: Saunders, Elsevier;. p.670-671

Schoenian, S. (2008): Infectious keratoconjunctivitis (pink eye). www.sheep and goats. Com /articles/pink eye.html.

Seeley, H.W. and Van Demark, P.J. (1981): Microbes in action a laboratory manual of microbiology. $3^{\text {rd }}$ ed. San Francisco: W.H .Freeman and Company; p.128-130.

Upadhyay, M.P.; Karmacharge, P.C. and Koirala S.T. (1991): Epidemiological characteristics pre-disposing factors and etiological diagnosis of corneal ulceration in Nepal. Am. J. Opthalmol. 111: 92-99.

\section{دراسة بكتيرية مقارنة لأسباب مرض التهاب القرنية والملتحمة في العين للسلالات المحلية للاغنام والماعز

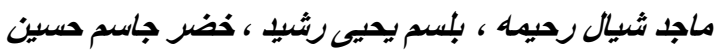

\footnotetext{
تم فحص 136 مسحة عين لغرض الفحص البكتيريولوجي و عزل وتثخيص بعض الجر اثيم المسببة لالتهاب الملتحمة و القرنية المعدي في الأغنام

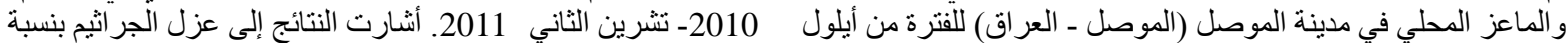

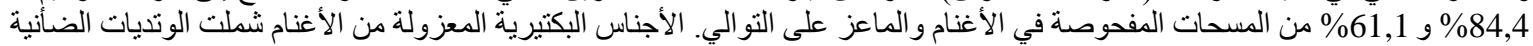

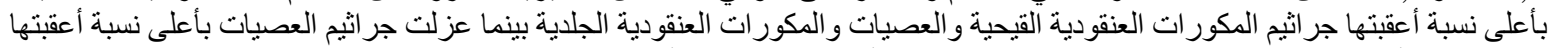

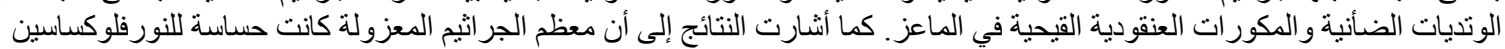
و الكلورمفينيكول.
} 